\title{
Hubungan Trait Mindfulness dan Keterikatan Kerja dengan Melibatkan Peran Mediasi Modal Psikologis
}

\author{
The Relationship between Trait Mindfulness and \\ Work Engagement Mediated by Psychological Capital
}

Arvidyani Anindita, Arum Etikariena

Fakultas Psikologi Universitas Indonesia

Email: arvidyani.a@gmail.com; arum.etikariena@ui.ac.id

\begin{abstract}
KATA KUNCI Keterikatan Kerja, Modal Psikologis, Trait Mindfulness.
KEYWORDS Psychological Capital, Trait Mindfulness, Work Engagement.
\end{abstract}

ABSTRAK Beberapa tahun terakhir, trait mindfulness mendapat banyak perhatian di dunia ilmiah. Penelitian-penelitian awal mengenai trait mindfulness di dunia kerja lebih berfokus pada kesejahteraan karyawan dan penurunan stres namun belum banyak diketahui dampaknya terhadap performa dan hasil kerja. Penelitian ini bertujuan untuk melihat dampak trait mindfulness terhadap keterikatan kerja karyawan, dengan modal psikologis sebagai mediator. Penelitian ini merupakan studi crosssectional dengan 591 karyawan kerah putih di Indonesia sebagai sampel. Alat ukur yang digunakan dalam penelitian ini adalah Mindful Attention Awareness Scale (MAAS), Utrecht Work Engagement Scale versi pendek (UWES-9), dan Psychological Capital Questionnaire (PCQ-12). Hasil analisis data menggunakan Model 4 PROCESS Hayes menunjukkan bahwa modal psikologis secara parsial memediasi hubungan antara trait mindfulness dan keterikatan kerja karyawan bahkan setelah mengontrol faktor demografis dan faktor organisasi (usia, jenis kelamin, tingkat pendidikan, masa kerja, tingkat jabatan, dan jenis organisasi). Hasil penelitian ini mengindikasikan adanya manfaat positif dari mengembangkan trait mindfulness dan modal psikologis karyawan.

ABSTRACT Trait mindfulness received great attention in academic research in the past years. Early research about trait mindfulness in the professional area focused on stress reduction and well-being outcomes yet little known its impact on performance and work-related outcomes. This study aimed to know trait mindfulness' impact on work engagement, with psychological capital as the mediator. This is cross-sectional study with 591 white-collar workers in Indonesia as the sample. The instrument used here were Mindful Attention Awareness Scale (MAAS), short version of Utrecht Work Engagement Scale (UWES-9), and Psychological Capital Questionnaire (PCQ-12). Analysis using Model 4 of PROCESS Hayes showed that psychological capital partially mediates the relationship 
between trait mindfulness and work engagement even after controlling demographic and organizational factors (age, sex, education level, job tenure, job level, and organization type). The findings of this study indicated the positive benefits of developing trait mindfulness and psychological capital in employees.

\section{PENDAHULUAN}

Pada dunia yang terus berubah, segala hal bergerak secara cepat. Perubahan besar dalam dunia bisnis selama dekade terakhir memiliki dampak besar pada tenaga kerja seperti perubahan gaya kerja, kemajuan dalam penggunaan teknologi, dan kesenjangan yang lebih besar antara keterampilan yang ada dan keterampilan yang dibutuhkan (Takwin, 2019). Perubahan yang terus menerus tersebut menciptakan suatu fenomena yang disebut VUCA (volatility, uncertainty, complexity, and ambiguity). Permintaan yang terus berubah dan meningkat dari internal dan eksternal organisasi berpotensi menjadi pemicu stres bagi karyawan. Sementara itu, di sisi lain karyawan harus memenuhi tuntutan pekerjaan tersebut. Karyawan harus menumbuhkan kelincahan (agility), fleksibilitas, dan ketahanan agar dapat sukses menghadapi dunia VUCA yang menantang dan tidak dapat diprediksi (Millar, Groth, \& Mahon, 2018). Resiliensi, fokus, dan dedikasi merupakan aspek penting bagi karyawan untuk menghadapi tantangan tersebut dan menjadi produktif. Hal ini dapat dicapai bila karyawan terikat dengan pekerjaannya. Keterikatan kerja (work engagement) adalah keadaan pikiran yang positif dan memuaskan terkait pekerjaan, yang dikonstruksi oleh tiga dimensi; vigour, dedication, dan absorption (Schaufeli, Salanova, González-Romá, \& Bakker, 2002). Vigour mengacu pada energi dan ketahanan mental yang tinggi saat bekerja dan menghadapi kesulitan. Individu dengan dedication yang tinggi sangat antusias, terinspirasi, dan tertantang dengan pekerjaan mereka, serta merasa pekerjaannya bermakna. Absorption ditandai dengan konsentrasi yang tinggi dan larut dalam pekerjaan tanpa menyadari berlalunya waktu, sehingga waktu terasa berjalan secara cepat (Schaufeli dkk, 2002; Petchsawang \& McLean, 2017; Bakker \& Albrecht, 2018). Keterikatan kerja dapat bermanfaat bagi individu, tim, dan organisasi, seperti meningkatkan kinerja, kreativitas, perilaku prososial, perilaku kewarganegaraan organisasi, dan kepuasan klien (Baker, Demerouti, \& Sanz-Vergel, 2014; Bakker \& Albrecht, 2018).

Hasil penelitian-penelitian empiris di Indonesia menunjukkan bahwa keterikatan kerja berpengaruh terhadap perilaku inovatif karyawan (Anwar \& Niode, 2017), perilaku proaktif (Deviyanti \& Sasono, 2015), kepuasan kerja dan penurunan intensi turnover (Merissa, 2018), serta berhubungan dengan kesejahteraan psikologis (Kimberly, 2013). Melihat pentingnya peran keterikatan kerja karyawan, perlu diketahui faktorfaktor apa saja yang dapat mempengaruhinya sehingga organisasi dapat meningkatkan keterikatan kerja karyawan. Hasil studi Ayu, Maarif, dan Sukmawati (2015) menunjukkan bahwa sumber daya individu (personal resources) lebih dapat memprediksi keterikatan kerja dibanding tuntutan pekerjaan (job demands) dan sumber daya pekerjaan (job resources).

Sejumlah penelitian telah dilakukan untuk melihat anteseden dari keterikatan kerja karyawan, baik dari sisi individu maupun organisasi. Kepemimpinan transformasional, persepsi dukungan organisasi, karakteristik pekerjaan, sumber daya pekerjaan, dan modal psikologis adalah beberapa anteseden dari keterikatan kerja. Jumlah studi tentang keterikatan kerja telah berkembang pesat selama dua dekade terakhir dan tren saat ini adalah melihat prediktor keterikatan kerja yang lebih jauh 
(Bakker \& Albrecht, 2018). Baru-baru ini, muncul sebuah anteseden baru dari keterikatan kerja yaitu mindfulness (Gunasekara \& Zheng, 2018; Malinowski \& Lim, 2015; Tabaziba, 2015; Kotzé, 2017; Wiroko \& Evanytha, 2019). Mindfulness adalah kesadaran yang muncul saat seseorang fokus pada momen saat ini, memperhatikan stimulus baru yang muncul, dan memproses stimulus tersebut secara netral tanpa bersikap reaktif atau menghakimi (Mesmer-Magnus, Manapragada, Viswesvaran, \& Allen, 2017). Individu yang mindful memperhatikan apa yang sedang terjadi saat ini, tidak banyak merenungkan tentang apa yang bisa terjadi di masa depan, atau pun terjebak di masa lalu. Individu tersebut menerima kejadian yang sedang berlangsung apa adanya, bukan memikirkan bagaimana yang seharusnya. Individu dengan mindfulness yang tinggi dapat mengamati dan menggambarkan apa yang terjadi baik di lingkungan eksternal diri maupun keadaan internal diri (pikiran, sensasi tubuh) tanpa penilaian, evaluasi, atau pun mencoba memberikan makna kepada kejadian-kejadian tersebut (Glomb, Duffy, Bono, \& Yang, 2011; Shapiro, Carlson, Astin, \& Freeman, 2006).

Mindfulness dapat dilihat sebagai suatu state dan juga trait. State mindfulness adalah kondisi saat seseorang menjadi mindful pada waktu tertentu. Frekuensi ratarata setiap orang dalam mengalami state mindfulness dapat berbeda-beda, yang mengindikasikan adanya kecenderungan disposisional seseorang terhadap mindfulness. Trait mindfulness mengacu pada kecenderungan disposisi seseorang terhadap mindfulness, artinya individu dengan trait mindfulness yang tinggi cenderung lebih sering mengalami state mindfulness dibanding individu dengan trait mindfulness yang rendah. Trait mindfulness dilihat seperti perbedaan individu yang cenderung bersifat stabil, sebagaimana trait kepribadian lainnya. Penelitian-penelitian sebelumnya lebih banyak menggali implikasi state mindfulness terhadap kesehatan dan kesuksesan diri, sehingga belum banyak diketahui bagaimana tendensi terhadap mindfulness (trait mindfulness) berhubungan dengan sikap dan perilaku seseorang serta kaitannya dengan personal dan professional outcome (Mesmer-Magnus dkk, 2017; Glomb dkk, 2011).

Saat ini mindfulness mendapat perhatian besar baik dalam dunia riset maupun profesional. Banyak perusahaan mengimplementasikan program intervensi berbasis mindfulness sebab program tersebut memiliki banyak manfaat. Untuk membuktikan efektivitas dan dampak dari program tersebut, penelitian empiris tentang mindfulness juga berkembang pesat, baik dalam konteks kehidupan sehari-hari dan juga konteks pekerjaan. Penelitian awal mengenai mindfulness fokus untuk melihat dampak mindfulness terhadap penurunan stres, burnout, dan juga peningkatan wellbeing (Samios, 2018; Taylor \& Millear, 2015; Malinowski \& Lim, 2015). Belum banyak diketahui dampak mindfulness terhadap performa dan hasil kerja lainnya. Di Indonesia sendiri, penelitian mengenai trait mindfulness masih sangat terbatas jumlahnya, terutama yang melihat perannya di dalam dunia kerja. Kebanyakan penelitian lebih melihat dampak mindfulness dalam konteks klinis dan kehidupan sehari-hari. Dengan demikian, masih banyak ruang untuk mengeksplorasi dampak trait mindfulness dalam konteks pekerjaan atau industri di Indonesia.

Penelitian-penelitian terbaru menggali manfaat mindfulness lebih dari sekedar penurunan stres dan peningkatan well-being. Mindfulness terbukti berkorelasi positif dengan kepuasan kerja, kepercayaan diri, regulasi emosi, keterampilan interpersonal, keterikatan kerja, dan kreativitas (Byrne \& Thatchenkery, 2019; Mesmer-Magnus dkk, 2017; Coo \& Salanova, 2017; Petchsawanga \& McLean, 2017; Malinowski \& Lim, 2015; Hülsheger, Alberts, Feinholdt, \& Lang, 2012). Sebaliknya, mindfulness berkorelasi negatif dengan emosi negatif, kelelahan emosional, kecemasan, depresi, burnout, perceived life 
stress, dan withdrawal (Mesmer-Magnus dkk, 2017; Hülsheger dkk, 2012).

Mindfulness dapat membuat seseorang menginterpretasikan kembali apa yang terjadi. Melalui mekanisme kognitif, individu dapat menyadari bahwa mereka bukanlah rasa sedih dan putus asa yang mereka rasakan. Mereka adalah individu yang terpisah dari emosi mereka dan kejadian yang mereka alami. Hal ini membuat individu tersebut dapat mengamati perasaannya tanpa merasa terikat dengan perasaan tersebut (Montani, DagenaisDesmarais, Giorgi, \& Grégoire, 2016). Dengan mempersepsikan ulang kejadiankejadian negatif yang dialami, kejadian tersebut dapat dipersepsi secara lebih positif dan bermakna, sehingga individu dapat lebih merasa berharap dan tertantang (Montani dkk, 2016; Garland, Gaylord, \& Park, 2009). Hal ini dapat berdampak baik bagi dimensi dedication dari keterikatan kerja, yang dicirikan dengan antusiasme, perasaan positif, dan tertantang.

Apabila individu mindful, maka ia mampu untuk melepas pikiran atau emosi yang dirasakan sebelumnya, dapat memberikan jarak antara dirinya dengan kejadian negatif yang dialami sehingga hal tersebut menurunkan dampak negatif kejadian tersebut terhadap dirinya. Mekanisme tersebut juga membuat individu dapat melihat berbagai hal secara lebih obyektif (Shapiro dkk, 2006). Dengan memberikan jarak antara diri dengan kejadian yang dialami, hal tersebut menurunkan kemungkinan individu untuk memikirkan hal yang kurang tepat mengenai kejadian negatif yang dialami dan melakukan perenungan yang tidak perlu (Shapiro dkk, 2006). Dengan demikian, energi yang biasanya digunakan untuk merenung dapat digunakan untuk tugastugas lain (Montani dkk, 2016). Hal ini berkaitan dengan dimensi vigour dari keterikatan kerja, yang dicirikan dengan tingginya energi individu.

Setelah mengembalikan sumber energi, dengan meningkatkan perhatian, mindfulness dapat membantu karyawan berkonsentrasi pada pekerjaannya. Konsentrasi tinggi ini sangat penting untuk mencapai keterikatan kerja (Petchsawang \& McLean, 2017; Montani dkk, 2016). Pikiran yang kuat dapat membantu karyawan untuk menyelesaikan masalah, menghadapi tantangan, dan menghadapi situasi sulit. Pikiran yang kuat juga dapat membantu karyawan untuk menjadi lebih resilien dalam menghadapi tantangan serta meningkatkan performa kerjanya, yang merupakan bagian krusial dari keterikatan kerja (Petchsawang \& McLean, 2017; Glomb dkk, 2011).

Anteseden penting lainnya dari keterikatan kerja adalah modal psikologis (psychological capital). Modal psikologis didefinisikan sebagai keadaan psikologis positif seseorang yang ditandai dengan: (1) memiliki keyakinan diri (self-efficacy) untuk menghadapi dan melakukan upaya yang diperlukan untuk berhasil dalam tugas-tugas yang menantang; (2) membuat atribusi positif atau optimis (optimism) tentang kesuksesan sekarang dan di masa depan; (3) gigih menggapai tujuan dan jika diperlukan akan mengubah rencana untuk mencapai tujuan agar dapat berhasil (hope); dan (4) ketika dilanda masalah dan kesulitan, mampu bertahan dan bangkit kembali, bahkan lebih kuat dari sebelumnya (resiliency) untuk mencapai kesuksesan. (Luthans \& Youssef, 2007). Banyak studi yang telah menemukan hubungan modal psikologis dengan keterikatan kerja (Sutrisno \& Parahyanti, 2017; Avey, Wernsing, \& Luthans, 2008; Tabaziba, 2015).

Modal psikologis terdiri dari empat aspek yang saling berhubungan, yaitu selfefficacy, resiliency, hope, dan optimism. Modal psikologis yang diukur sebagai konstruk tunggal lebih dapat memprediksi performa dan kepuasan dibanding apabila diukur melalui keempat aspeknya secara terpisah (Luthans, Avolio, Avey, \& Norman, 2007). Modal psikologis juga berkorelasi positif dengan kesejahteraan psikologis, komitmen organisasi, perilaku kewarganegaraan karyawan, dan berkorelasi negatif dengan sinisme, intensi turnover, 
stres kerja, dan kecemasan (Avey, Reichard, Luthans, \& Mhatre, 2011). Modal psikologis tidak bersifat stabil seperti trait yang disposisional dan relatif stabil dari waktu ke waktu, namun modal psikologis juga bukan keadaan sementara (state). Modal psikologis berada di antara sifat stabil dan dapat berubah sehingga dapat diubah dan dikembangkan (Luthans dkk, 2007). Penggunaan istilah 'modal' dalam modal psikologis juga menunjukkan bahwa hal tersebut adalah sesuatu yang dapat dikembangkan dan dapat bermanfaat untuk meningkatkan performa dan hasil kerja.

Modal psikologis adalah salah satu sumber daya individu yang mempengaruhi keterikatan kerja. Studi sebelumnya menunjukkan bahwa modal psikologis adalah anteseden dari keterikatan kerja (Tabaziba, 2015; Daniswara, 2012; Avey $\mathrm{dkk}, 2008)$. Masing-masing dimensi modal psikologis (self-efficacy, resiliency, hope, dan optimism) juga secara independen berkorelasi dengan keterikatan kerja (Simons \& Buitendach, 2013; Bakker, 2009; Xanthopoulou, Bakker, Demerouti, \& Schaufeli, 2007). Salah satu penjelasan mengapa modal psikologis berdampak pada keterikatan kerja adalah karena modal psikologis dapat meningkatkan perasaan positif sehingga karyawan lebih mungkin untuk terikat dengan pekerjaannya (Avey dkk, 2008). Karyawan dengan modal psikologis yang tinggi akan lebih terikat dan lebih antusias dengan pekerjaannya (Avey dkk, 2011).

Modal psikologis baik sebagai konstruk tunggal maupun masing-masing aspeknya juga berkorelasi dengan mindfulness (Tabaziba, 2015; Avey dkk, 2008). Seseorang merasa percaya diri dengan kemampuannya, optimis dalam melihat keadaan, dan mampu bangkit kembali dari situasi yang penuh tekanan adalah proses mental di belakang modal psikologis. Proses mental ini dapat difasilitasi dengan mindfulness yang melibatkan regulasi diri dan perhatian netral tanpa bersikap reaktif dan menghakimi stimulus yang ada (Roche, Haar, \& Luthans,
2014). Mindfulness membantu karyawan untuk memisahkan diri dari kejadian yang menimpanya dan meningkatkan kesadaran karyawan tentang pola pikirnya, sehingga memungkinkan dirinya untuk secara sengaja memilih untuk menjadi lebih penuh harapan, yakin, optimis, dan resilien dalam menghadapi tuntutan pekerjaan dan stres kerja (Avey dkk, 2008; Mesmer-Magnus dkk, 2017). Karyawan yang mindful cenderung lebih menyadari pikiran dan emosi mereka, sehingga mindfulness menjadi kunci penting dalam mengubah pemikiran dan respons emosional mereka. (Tabaziba, 2015). Mindfulness dapat mengurangi perenungan yang tidak diperlukan dan meningkatkan regulasi diri (Roche, Haar, \& Luthans, 2014) yang berujung pada performa dan hasil kerja yang lebih baik. Saat ini penelitian yang menggali hubungan antara trait mindfulness dan modal psikologis masih terbatas jumlahnya, sehingga diperlukan penelitian-penelitian baru.

Dengan menjadi mindful, seseorang cenderung tidak berespon secara otomatis dalam menanggapi suatu stimulus sebab melalui perhatian penuh, karyawan dapat memilih reaksi mereka terhadap stimulus yang ada, termasuk memilih untuk menjadi lebih positif dalam menanggapi stimulus tersebut. Dengan kata lain, mindfulness dapat meningkatkan keberfungsian seseorang secara lebih positif terutama saat menghadapi kesulitan dan kejadian negatif (Hülsheger dkk, 2012). Avey dkk (2008) menemukan bahwa modal psikologis berinteraksi dengan mindfulness dalam memprediksi emosi positif. Ketika modal psikologis rendah, mindfulness yang tinggi dapat memprediksi emosi positif. Emosi positif ini kemudian berhubungan dengan dengan engagement. Karyawan dengan selfefficacy, optimism, dan resiliency yang tinggi terbukti lebih terikat dengan pekerjaan mereka (Mäkikangas dkk, 2013).

Studi lain mengeksplorasi hubungan antara aspek-aspek modal psikologis dengan aspek mindfulness (acting aware, nonjudging, describing, dan non-reacting), dan 
keterikatan kerja sebagai konstruk tunggal (Malinowski \& Lim, 2015). Studi ini menunjukkan bahwa dengan meningkatkan perasaan positif, harapan, dan optimisme, modal psikologis memediasi hubungan antara mindfulness dan keterikatan kerja. Penelitian Kotzé (2017) juga menunjukkan bahwa modal psikologis secara parsial memediasi hubungan antara mindfulness dan dua dimensi keterikatan kerja (vigour dan dedication). Berbeda dari penelitian sebelumnya yang melihat hubungan di tingkat dimensi, semua variabel dalam penelitian ini dilihat sebagai konstruk tunggal.

Di sisi lain, penelitian lain menunjukkan bahwa hubungan antara modal psikologis dan keterikatan kerja dimediasi oleh mindfulness (Tabaziba, 2015). Hasil ini menimbulkan pertanyaan tentang arah hubungan, apakah mindfulness atau modal psikologis yang menjadi mediator hubungan tersebut. Secara logis, trait mindfulness seharusnya menjadi anteseden yang lebih dahulu sebab trait adalah sesuatu yang bersifat disposisi dan empat aspek modal psikologis (self-efficacy, resiliency, hope, dan optimism) adalah sesuatu yang dapat diubah dan dipelajari dari waktu ke waktu. Dengan demikian, dapat dikatakan bahwa modal psikologis merupakan hasil dari trait mindfulness. Roche, Haar, dan Luthans (2014) juga menemukan bahwa modal psikologis merupakan mediator antara hubungan mindfulness dan kesehatan mental.

Penelitian ini bertujuan untuk melihat dampak trait mindfulness terhadap keterikatan kerja, dengan modal psikologis sebagai mediator. Berbeda dari penelitian sebelumnya yang melihat hubungan di tingkat dimensi, semua variabel dalam penelitian ini dilihat sebagai konstruk tunggal.

Hipotesis: Trait mindfulness memiliki pengaruh tidak langsung terhadap keterikatan kerja melalui modal psikologis sebagai mediator.

\section{METODE PENELITIAN Pendekatan}

Penelitian ini menggunakan pendekatan kuantitatif tipe korelasional dengan desain studi cross-sectional dan non eksperimental.

\section{Partisipan}

Data dikumpulkan melalui survei online dan offline. Tautan survey online disebarkan melalui LinkedIn, Facebook, WhatsApp, dan Line. Teknik convenience sampling dipilih untuk penelitian ini. Sebanyak 591 pekerja kerah putih di Indonesia berpartisipasi dalam penelitian ini. Dari data yang terkumpul, 69,5\% adalah perempuan, 28,9\% laki-laki, dan 1,5\% lainnya tidak menyebutkan jenis kelaminnya. Usia responden berkisar antara 18 hingga 56 tahun $(M=28,81, S D=8,31)$. Sebagian besar responden memiliki latar belakang pendidikan S-1 (72,8\%). Sisanya memiliki latar belakang pendidikan S-3, S2, diploma, dan juga sekolah menengah atas. Para responden bekerja di berbagai jenis organisasi (institusi pemerintahan, BUMN, swasta, organisasi nirlaba, dan lainnya) dengan tingkat jabatan yang beragam

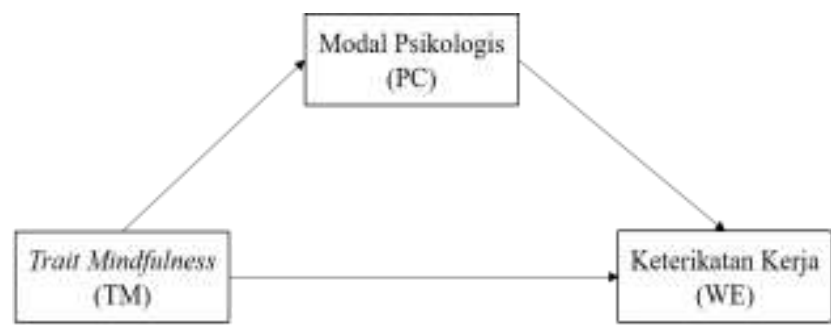

Gambar 1. Modal psikologis sebagai mediator antara trait mindfulness dan keterikatan kerja. 
(direktur, general manager, manajer, supervisor, staf, dan lainnya). Mayoritas responden $(55,5 \%)$ bekerja selama kurang dari 2 tahun di tempat kerja mereka saat ini, sementara 38,2\% telah bekerja selama 3-10 tahun, 5,9\% telah bekerja selama lebih dari 10 tahun, dan 0,3\% tidak menyebutkan masa kerjanya.

\section{Instrumen}

Tiga alat ukur digunakan dalam penelitian ini untuk mengukur trait mindfulness, keterikatan kerja, dan modal psikologis. Trait mindfulness diukur menggunakan Mindful Attention Awareness Scale (MAAS). MAAS terdiri dari 15 aitem yang mengukur trait mindfulness sebagai konstruk unidimensional yang meliputi domain kognitif, emosional, dan fisik (Brown \& Ryan, 2003).

Beberapa alat ukur trait mindfulness digunakan untuk konteks spesifik, seperti misalnya Managerial Mindfulness Measure (Han \& Zhang, 2011) yang melihat predisposisi mindfulness seseorang dalam situasi manajerial. Sementara itu, MAAS bersifat umum dan dapat digunakan di berbagai konteks termasuk pekerjaan.

Skala MAAS menggunakan 7 pilihan respon mulai dari 1 "hampir selalu" sampai 7 "hampir tidak pernah". Semua aitem pada alat ukur ini dinilai secara terbalik (reverse) (Mesmer-Magnus dkk, 2017). Nilai Cronbach alpha skala ini adalah 0,859 .

Pengukuran keterikatan kerja menggunakan Utrecht Work Engagement Scale versi pendek (UWES-9). UWES-9 terdiri dari 9 aitem yang mengukur 3 dimensi keterikatan kerja; vigour, dedication, dan absorption (Schaufeli dkk, 2002). Schaufeli, Bakker, dan Salanova (2006) menyarankan untuk melihat skor total dibanding per dimensi kecuali apabila tujuannya untuk menggali informasi lebih dalam mengenai setiap dimensi. UWES-9 menggunakan skala 6 poin dari 1 "tidak pernah" sampai 6 "selalu". Nilai Cronbach alpha skala ini adalah 0,917 .
Psychological

Capital Questionnaire (PCQ-12) digunakan untuk mengukur modal psikologis (Avey, Avolio, \& Luthans, 2011). Alat ukur ini merupakan versi pendek dari PCQ yang memiliki 24 aitem. PCQ-12 memiliki 12 aitem dan digunakan skor total untuk mengukur modal psikologis sebagai sebuah konstruk tunggal. Alat ukur ini menggunakan skala Likert mulai dari 1 "sangat tidak setuju" sampai 6 "sangat setuju". Nilai Cronbach alpha skala ini adalah 0,782 .

Minimalisasi common method bias dilakukan dengan beberapa upaya, yaitu: (1) mengacak urutan aitem, (2) mengacak urutan penyajian alat ukur (counterbalancing question order) pada kuesioner dengan membuat beberapa versi kuesioner, (3) menjaga anonimitas responden, (4) menyampaikan bahwa tidak ada jawaban benar dan salah, dan (5) melakukan analisis statistik Harman's single-factor test (Podsakoff, MacKenzie, Lee, \& Podsakoff, 2003).

\section{Teknik Analisis Data}

Pengujian hipotesis menggunakan Model 4 dari PROCESS version 3.3 for IBM SPSS dengan 10.000 bootstraps (Hayes, 2013). Skor yang digunakan untuk analisis data adalah skor total dari masing-masing alat ukur. Harman's single-factor test digunakan untuk mengukur sejauh mana common method variance (CMV) mungkin muncul di antara hubungan antarvariabel. Hasilnya menunjukkan bahwa CMV hanya menyumbang $21 \%$ dari varians data penelitian ini, sehingga tidak menjadi masalah karena jatuh di bawah ambang batas 50\% (Dupuis, Khadeer, \& Huang, 2017).

\section{ANALISIS DAN HASIL}

Hasil uji korelasi bivariat pada Tabel 1 menunjukkan bahwa semua variabel kunci pada penelitian ini saling berkorelasi secara positif. Berdasarkan analisis mediasi sederhana menggunakan ordinary least squares path analysis, ditemukan bahwa trait mindfulness mempengaruhi keterikatan kerja melalui modal psikologis. Hasil 
Tabel 1

Korelasi Bivariat antar Variabel Kunci

\begin{tabular}{llrrcc}
\hline & $M$ & \multicolumn{1}{c}{$S D$} & 1 & 2 & 3 \\
\hline 1. Trait mindfulness (TM) & 59,50 & 10,46 & - & & \\
2. Keterikatan kerja (WE) & 39,40 & 8,77 & $0,287 * * *$ & - & - \\
3. Modal psikologis (PC) & 55,09 & 6,25 & $0,317 * * *$ & $0,483 * * *$ & - \\
\hline$* * * p<0,001$ & & & &
\end{tabular}

analisis juga menunjukkan bahwa trait mindfulness berpengaruh secara positif terhadap keterikatan kerja $(c=0,241, \mathrm{SE}=$ $0,33, t=7,270, p<0,001$, LLCI $=0,176$, ULCI $=0,306)$. Seperti yang dapat dilihat pada gambar 2 dan tabel 2, responden dengan trait mindfulness yang lebih tinggi akan memiliki tingkat modal psikologis yang lebih tinggi ( $a=0,190, p<0,001)$, dan responden yang memiliki modal psikologis yang lebih tinggi juga akan lebih terikat dengan pekerjaannya $(b=0,611, p<0,001)$. Bias-corrected bootstrap confidence interval untuk pengaruh tidak langsung ( $a b$ $=0,116)$ berdasarkan 10.000 sampel bootstrap seluruhnya berada di atas $0(0,083$ sampai 0,153). Ini menunjukkan bahwa modal psikologis memediasi hubungan antara trait mindfulness dan keterikatan kerja. Dengan demikian, hipotesis diterima. Di sisi lain, ditemukan terdapat pengaruh langsung dari trait mindfulness terhadap keterikatan kerja $\left(c^{\prime}=0,125, \mathrm{SE}=0,032, t=\right.$ 3,960, $p<0,001$, LLCI $=0,063$, ULCI $=$ 0,187 ) yang berarti model penelitian ini adalah model mediasi parsial. Bila dilihat lebih jauh, pengaruh langsung dari trait mindfulness terhadap keterikatan kerja $\left(c^{\prime}=\right.$ $0,125)$ lebih besar dibanding pengaruhnya melalui mediator $(a b=0,116)$.

Selanjutnya, usia, jenis kelamin, tingkat pendidikan, masa kerja, tingkat jabatan, dan tipe organisasi dikontrol, sebab penelitian-penelitian terdahulu menunjukan bahwa variabel-variabel tersebut berpotensi untuk memiliki dampak terhadap keterikatan kerja (Rotich, Cheruiyot, \& Korir, 2016; Chaudhary \& Rangnekar, 2017; Jaworek, 2017; Gunasekara \& Zheng, 2018). Hasilnya menunjukkan bahwa usia secara signifikan berkorelasi dengan modal psikologis, yang mana responden dengan usia yang lebih tua cenderung lebih resilien, penuh harapan, optimis, dan percaya diri mengenai kapabilitas dirinya $\left(f_{1}=0,091, p<0,05\right)$ dan responden tersebut juga lebih terikat dengan pekerjaan dibanding responden dengan usia yang lebih muda $\left(g_{1}=0,088, p<0,05\right)$. Tingkat jabatan juga berkorelasi secara signifikan dengan modal psikologis $\left(f_{5}=\right.$ $0,190, p<0,05)$, yang mana responden dengan tingkat jabatan yang lebih rendah akan memiliki tingkat modal psikologis yang lebih tinggi dibanding responden dengan tingkat jabatan yang lebih tinggi. Selain kedua variabel tersebut, tidak ada variabel kontrol lainnya yang berkorelasi secara signifikan dengan keterikatan kerja dan modal psikologis.

Setelah variabel demografis dikontrol, terdapat sedikit penurunan hasil meskipun semua efek masih signifikan. Hasilnya disajikan pada Gambar 3 dan Tabel 3. Seperti yang dapat dilihat, responden

Tabel 2

Pengaruh Trait Mindfulness dan Modal Psikologis terhadap Keterikatan Kerja

\begin{tabular}{|c|c|c|c|c|c|c|c|c|}
\hline \multirow[b]{3}{*}{ Anteseden } & & \multicolumn{7}{|c|}{ Consequent } \\
\hline & & \multicolumn{3}{|c|}{$M(\mathrm{PC})$} & & \multicolumn{3}{|c|}{$Y(\mathrm{WE})$} \\
\hline & & Koefisien & $S E$ & $p$ & & Koefisien & $S E$ & $p$ \\
\hline$X(\mathrm{TM})$ & $a$ & 0,190 & 0,023 & 0,000 & $c^{\prime}$ & 0,125 & 0,032 & 0,000 \\
\hline$M(\mathrm{PC})$ & & - & - & - & $b$ & 0,611 & 0,053 & 0,000 \\
\hline \multirow[t]{2}{*}{ Konstan } & $i_{1}$ & 43,808 & 1,411 & 0,000 & $i_{2}$ & $-1,696$ & 2,932 & 0,563 \\
\hline & & \multicolumn{3}{|c|}{$R^{2}=0,101$} & & \multicolumn{3}{|c|}{$R^{2}=0,253$} \\
\hline
\end{tabular}




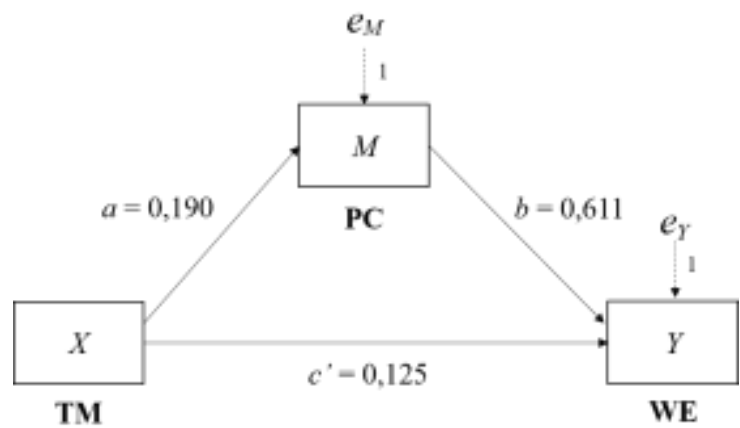

Gambar 2. Model mediasi.

dengan tingkat trait mindfulness yang lebih tinggi akan memiliki tingkat modal psikologis yang juga lebih tinggi ( $a=0,174$, $p<0,001)$, dan responden yang memiliki tingkat modal psikologis yang lebih tinggi juga akan memiliki tingkat keterikatan kerja yang lebih tinggi $(b=0,605, p<0,001)$. Bias-corrected bootstrap confidence interval untuk pengaruh tidak langsung ( $a b$ $=0,105)$ berdasarkan 10.000 sampel bootstrap berada di atas $0(0,071$ sampai 0,139).

Selain itu, terbukti bahwa trait mindfulness memiliki pengaruh langsung terhadap keterikatan kerja terlepas dari pengaruhnya terhadap modal psikologis $(c$ ' $=0,113, \mathrm{SE}=0,032, t=3,524, p<0,001$, $\mathrm{LLCI}=0,050, \mathrm{ULCI}=0,176)$. Dapat dilihat bahwa secara substantif, tidak ada yang benar-benar berubah dari sebelum dan sesudah mengontrol variabel demografis. Efek langsung dan tidak langsung dari trait mindfulness terhadap keterikatan kerja melalui modal psikologis masih positif bahkan setelah menyesuaikan kemungkinan efek confounding atau hubungan epifenomenal dari keenam kovariat tersebut.

Tabel 3

Pengaruh Faktor Demografis dan Organisasi terhadap Modal Psikologis dan Keterikatan Kerja

\begin{tabular}{|c|c|c|c|c|c|c|c|c|}
\hline \multirow{3}{*}{\multicolumn{2}{|c|}{ Anteseden }} & \multicolumn{7}{|c|}{ Consequent } \\
\hline & & \multicolumn{3}{|c|}{$M(\mathrm{PC})$} & & \multicolumn{3}{|c|}{$Y(\mathrm{WE})$} \\
\hline & & Koefisien & $S E$ & $p$ & & Koefisien & $S E$ & $p$ \\
\hline$X(\mathrm{TM})$ & $a$ & 0,174 & 0,024 & 0,000 & $c^{\prime}$ & 0,113 & 0,032 & 0,000 \\
\hline$M(\mathrm{PC})$ & & - & - & - & $b$ & 0,605 & 0,055 & 0,000 \\
\hline$C_{1}$ (USIA) & $f_{1}$ & 0,091 & 0,031 & 0,004 & $g_{1}$ & 0,088 & 0,041 & 0,031 \\
\hline$C_{2}(\mathrm{JENIS}$ KELAMIN) & $f_{2}$ & 0,008 & 0,036 & 0,815 & $g_{2}$ & 0,018 & 0,046 & 0,701 \\
\hline$C_{3}(\mathrm{PENDIDIKAN})$ & $f_{3}$ & $-0,043$ & 0,039 & 0,262 & $g_{3}$ & 0,001 & 0,050 & 0,991 \\
\hline$C_{4}$ (MASA KERJA) & $f_{4}$ & 0,028 & 0,060 & 0,644 & $g_{4}$ & 0,014 & 0,078 & 0,862 \\
\hline$C_{5}(\mathrm{JABATAN})$ & $f_{5}$ & $-0,190$ & 0,090 & 0,035 & $g_{5}$ & $-0,006$ & 0,116 & 0,960 \\
\hline$C_{6}$ (ORGANISASI) & $f_{6}$ & 0,273 & 0,302 & 0,366 & $g_{6}$ & $-0,066$ & 0,391 & 0,867 \\
\hline Konstan & $i_{1}$ & 42,191 & 1,807 & 0,000 & $i_{2}$ & $-3,087$ & 3,245 & 0,342 \\
\hline & & \multicolumn{3}{|c|}{$R^{2}=0,126$} & & \multicolumn{3}{|c|}{$R^{2}=0,262$} \\
\hline & & \multicolumn{3}{|c|}{$F(7,583)=12,061, p=0,000$} & & \multicolumn{3}{|c|}{$F(8,582)=25,771, p=0,000$} \\
\hline
\end{tabular}




\section{DISKUSI}

Ada beberapa pandangan berbeda tentang hubungan antara mindfulness, modal psikologis, dan keterikatan kerja; Beberapa berpendapat bahwa mindfulness memediasi hubungan modal psikologis dan keterikatan kerja (Tabaziba, 2015), sedangkan yang lain berpendapat bahwa hubungan antara mindfulness dan keterikatan kerja dimediasi oleh modal psikologis (Kotzé, 2017; Malinowski \& Lim, 2015). Hasil penelitian ini mendukung argumen kedua. Mungkin karena trait mindfulness adalah karakteristik disposisional yang lebih stabil daripada modal psikologis yang berada di antara trait dan state (Luthans dkk, 2007).

Hasil yang menunjukkan bahwa trait mindfulness memiliki pengaruh positif terhadap keterikatan kerja melalui modal psikologis sejalan dengan temuan Malinowski dan Lim (2015) serta Kotzé (2017). Penelitian sebelumnya menunjukkan bahwa mindfulness dapat meningkatkan harapan, optimisme, dan perasaan positif, sehingga menghasilkan keterikatan kerja yang lebih tinggi. Dengan mempersepsi kembali kejadian-kejadian negatif yang dialami, kejadian tersebut dapat dilihat secara lebih positif dan bermakna, sehingga individu merasa lebih memiliki harapan dan merasa tertantang (Montani dkk, 2016; Garland, Gaylord, \& Park, 2009). Penelitian sebelumnya menunjukkan bahwa mindfulness bersama dengan modal psikologis dapat memprediksi emosi positif, dan emosi positif tersebut memediasi hubungan antara modal psikologis dan engagement (Avey dkk, 2008). Depenbrock (2014) juga menemukan bahwa hubungan antara mindfulness dan keterlibatan kerja dimediasi oleh perasaan positif. Sementara variabel lain yang juga memediasi hubungan antara mindfulness dan keterlibatan kerja adalah Psychological flourisihing (Zheng, Gunasekara, \& Blaich, 2018). Sebaliknya, penelitian lain menemukan bahwa mindfulness secara parsial memediasi hubungan antara modal psikologis dan keterikatan kerja (Tabaziba, 2015).
Temuan penelitian ini mendukung gagasan bahwa karyawan yang lebih mindful akan lebih percaya diri, resilien, penuh harapan, dan optimis sehingga dapat lebih terikat dengan pekerjaannya. Hasil penelitian menunjukkan bahwa hubungan trait mindfulness dan keterikatan kerja dimediasi secara parsial oleh modal psikologis.

Mediasi parsial ini terjadi karena selain memiliki pengaruh tidak langsung melalui peran mediasi modal psikologis, trait mindfulness masih memiliki pengaruh langsung terhadap keterikatan kerja setelah mengontrol pengaruhnya terhadap modal psikologis. Ini artinya mekanisme pada trait mindfulness dapat secara langsung mempengaruhi keterlibatan kerja karyawan tanpa melalui modal psikologis. Dengan menaruh perhatian penuh pada momen saat ini (mindful), karyawan dapat menghindari distraksi sehingga bisa lebih fokus pada tugas dan terikat dengan pekerjaan mereka (Gunasekara \& Zheng, 2018), terlepas dari apakah modal psikologis karyawan tersebut meningkat atau tidak.

Pada lingkungan kerja yang sulit dan menantang dengan tugas-tugas yang kompleks, karyawan yang mempersepsikan situasi dengan netral dan tidak menghakimi cenderung melihat keadaan secara obyektif. Karyawan tersebut menerima situasi yang ada dan cenderung lebih mampu untuk meregulasi emosinya saat menemui situasi yang sulit penuh tekanan. Karyawan tersebut juga memilih untuk bersikap lebih positif, bekerja secara progresif, dan menjalin hubungan interpersonal yang baik di tempat kerja (Glomb dkk, 2011; Gunasekara \& Zheng, 2018).

Pengaruh langsung trait mindfulness pada keterikatan kerja konsisten dengan penelitian-penelitian terbaru yang juga mengeksplorasi hubungan antara mindfulness dan keterikatan kerja (Malinowski \& Lim, 2015; Gunasekara \& Zheng, 2018). Hasil ini menunjukkan bahwa untuk mendapatkan karyawan yang terikat dengan pekerjaannya, organisasi harus lebih 
memperhatikan dan berupaya mendapatkan karyawan yang mindful.

Hasil penelitian ini menunjukkan bahwa dibanding trait mindfulness, modal psikologis memiliki pengaruh yang lebih besar terhadap keterikatan kerja. Pengaruh langsung dari modal psikologis terhadap keterikatan kerja menunjukkan bahwa dengan memiliki self-efficacy, resiliensi, optimisme, dan harapan yang tinggi, karyawan dapat lebih fokus, antusias, dan berdedikasi pada pekerjaannya. Salah satu alasan mengapa modal psikologis memiliki dampak pada keterikatan kerja adalah karena modal psikologis dapat meningkatkan perasaan positif sehingga karyawan cenderung lebih terikat dengan pekerjaannya (Avey dkk, 2008). Temuan ini sejalan dengan penelitian-penelitian sebelumnya (Tabaziba, 2015; Daniswara, 2012; Avey dkk, 2011; Avey dkk, 2008).

Langkah berikutnya yang perlu dilakukan setelah melakukan analisis mediasi adalah melihat perbedaan setelah mengontrol variabel-variabel yang dapat mempengaruhi variabel hasil atau variabel mediator. Tujuannya adalah untuk mengurangi kemungkinan efek confounding atau hubungan epifenomenal (Hayes, 2013). Pada penelitian ini, usia terbukti berhubungan secara signifikan dengan modal psikologis dan keterikatan kerja. Temuan ini sejalan dengan penelitian sebelumnya yang menemukan bahwa usia berkorelasi dengan dampak mindfulness terhadap keterikatan kerja, yang mengindikasikan bahwa pekerja dengan usia yang lebih tua lebih terikat dengan pekerjaannya (Gunasekara \& Zheng, 2018; Chaudary \& Rangnekar, 2017; Jaworek, 2017; Rotich, Cheruiyot, \& Korir, 2016). Dari perspektif budaya, mungkin pekerja yang lebih tua sudah melakukan praktikpraktik mindfulness sebab masyarakat Indonesia cenderung lebih religius dan melakukan ritual-ritual keagamaan yang mirip dengan praktik mindfulness. Praktikpraktik ini dapat membantu orang tersebut untuk lebih memiliki sikap positif (hope dan optimism), resiliensi, dan kepercayaan diri dalam menghadapi situasi hidup yang sulit, sehingga lebih dapat terikat dengan pekerjaannya.

Jenis kelamin, tingkat pendidikan, dan masa kerja tidak terbukti menjadi kovariat sebagaimana ditemukan pada beberapa penelitian sebelumnya (Gunasekara \& Zheng, 2018; Chaudhary \& Rangnekar, 2017; Rotich, Cheruiyot, \& Korir, 2016). Selain itu, tipe organisasi (pemerintahan, swasta, BUMN, dan organisasi nirlaba) juga tidak memiliki dampak terhadap keterikatan kerja. Hal ini berbeda dengan penelitian sebelumnya yang menemukan bahwa karyawan dari perusahaan swasta memiliki keterikatan kerja yang lebih tinggi dibanding karyawan yang berasal dari institusi pemerintahan, sebab perusahaan swasta cenderung lebih banyak memberikan tantangan secara rutin sedangkan institusi pemerintahan lebih menawarkan rasa aman (job security) yang membuat karyawan tersebut cenderung lebih santai dan tidak terlalu terikat dengan pekerjaannya (Chaudhary \& Rangnekar, 2017).

Perbedaan yang kecil antara sebelum dan sesudah mengontrol variabel demografis menunjukkan bahwa keenam kovariat tidak benar-benar mempengaruhi hubungan mediasi antara trait mindfulness dan keterikatan kerja melalui modal psikologis. Meskipun demikian, tetap ada kemungkinan bahwa terdapat variabel confounding lainnya yang tidak diukur dalam penelitian ini.

Hasil penelitian ini menunjukkan bahwa trait mindfulness dan modal psikologis adalah sumber daya individu yang dapat mempengaruhi keterikatan kerja karyawan. Trait mindfulness dapat memperkuat keyakinan individu bahwa ia memiliki apa yang ia butuhkan untuk dapat sukses (self-efficacy) dan membantunya untuk tetap resilien, penuh harapan, dan optimis meskipun menemui situasi yang sulit, menantang, kompleks, dan penuh tekanan. Akibatnya, karyawan dapat lebih terikat dengan pekerjaannya dan memiliki performa yang lebih baik (Kotzé, 2017). Hal 
ini dapat membantu karyawan tersebut untuk sukses menghadapi dunia VUCA.

Hasil penelitian ini memiliki kontribusi yang cukup besar terhadap pengembangan literatur trait mindfulness pada konteks dunia kerja terutama di Indonesia, sebab di Indonesia belum banyak penelitian yang bertujuan melihat dampak trait mindfulness di dunia kerja. Kebanyakan penelitian di Indonesia lebih melihat dampak mindfulness dalam konteks klinis. Penelitian-penelitian terdahulu mengenai dampak trait mindfulness juga masih berfokus pada penurunan stres dan peningkatan well-being, namun belum banyak yang mengeksplorasi dampaknya terhadap hasil kerja. Lebih khusus, hasil penelitian ini dapat memperkaya literatur mengenai trait mindfulness dan kaitannya dengan modal psikologis dan keterikatan kerja karyawan.

Beberapa manfaat praktis dapat diambil dari hasil penelitian ini. Pertama, setelah trait mindfulness dan modal psikologis terbukti menjadi sumber daya individu yang dapat berdampak pada keterikatan kerja, organisasi bisa mulai fokus untuk meningkatkan kedua hal tersebut. Tujuannya agar karyawan memiliki sumber daya individu yang lebih besar untuk lebih fokus bekerja serta dapat menghadapi berbagai tantangan pekerjaan dan situasisituasi yang sulit dan penuh tekanan.

Organisasi

dapat

mengimplementasikan intervensi berbasis mindfulness seperti pelatihan mindfulness, Mindfulness-Based Stress Reduction (MBSR), Mindfulness-Based Cognitive Therapy (MBCT), dan Acceptance and Commitment Therapy (ACT) sebab program-program intervensi tersebut merupakan cara yang baik untuk meningkatkan tingkat state mindfulness karyawan terlepas dari predisposisi karyawan tersebut terhadap trait mindfulness (Mesmer-Magnus dkk, 2017).

Program intervensi berbasis mindfulness terbukti bermanfaat bagi individu dan pekerjaannya, seperti keterikatan kerja (Petchsawanga \& McLean,
2017; Coo \& Salanova, 2017), kebahagiaan dan performa (Coo \& Salanova, 2017), kreativitas (Byrne \& Thatchenkery, 2019), kepuasan kerja, dan juga menurunkan kelelahan emosional (Hülsheger dkk, 2012). Selain itu organisasi dapat menambahkan program-program yang dapat meningkatkan mindfulness seperti kelas meditasi dan yoga ke dalam program wellness karyawan.

Organisasi juga dapat mengimplementasikan program yang dapat meningkatkan modal psikologis karyawan sebab dibanding trait mindfulness, modal psikologis lebih mempengaruhi keterikatan kerja. Hal ini dapat dicapai melalui pemberian pelatihan modal psikologis yang meliputi strategi coping secara kognitif, emosi, dan reaksi saat menemui permasalahan, meningkatkan kepercayaan diri, dan mengembangkan ekspektasi yang positif (Luthans, Youssef, \& Avolio, 2007).

Selain meningkatkan modal psikologis dan mindfulness karyawan, organisasi juga dapat mempertimbangkan kedua variabel tersebut dalam rekrutmen calon karyawan. Organisasi dapat merekrut kandidat yang memiliki tingkat trait mindfulness dan modal psikologis yang tinggi. Penggunaan tes kepribadian saat seleksi karyawan dapat membantu organisasi dalam mengidentifikasi dan mendapatkan kandidat yang sudah memiliki trait mindfulness dan modal psikologis yang tinggi. Hal ini dapat membantu organisasi dalam mendapatkan hasil kerja yang positif serta menurunkan biaya dan usaha untuk meningkatkan mindfulness, modal psikologis, dan keterikatan kerja karyawan.

Meskipun terdapat beberapa manfaat dari penelitian ini, penelitian ini juga tetap memiliki sejumlah keterbatasan. Data crosssectional yang diperoleh dari self-report survey dapat menimbulkan bias respon. Data cross-sectional dan teknik convenience sampling yang digunakan juga membuat hasil penelitian ini kurang dapat digeneralisasi. Generalisasi dari metode ini perlu dilakukan secara hati-hati (Cohen \& Swerdlik, 2009). 
Bila dilihat dari kerangka teoritis, ada beberapa pandangan yang berbeda tentang konsep mindfulness berikut cara pengukurannya. Sebagian peneliti melihat mindfulness sebagai state dan sebagian lainnya melihat mindfulness sebagai trait. Pada penelitian-penelitian sebelumnya, pengukuran state maupun trait mindfulness kerap menggunakan alat ukur yang sama, sehingga dapat dikatakan belum ada batasan yang jelas bagaimana mindfulness diukur sebagai state atau trait. Pandangan lain yang juga berbeda mengenai konsepsi dan cara pengukuran mindfulness adalah sebagian peneliti melihatnya sebagai konstruk multidimensional (Gunasekara \& Zheng, 2018; Malinowski \& Lim, 2015) dan sebagian lainnya melihatnya sebagai unidimensional (Kotzé, 2017; Brown \& Ryan, 2003; Depenbrock, 2014).

Pada penelitian ini, trait mindfulness diukur menggunakan MAAS yang melihat konstruk tersebut sebagai unidimensional. Penelitian selanjutnya dapat mengeksplorasi konsep trait mindfulness lainnya untuk melihat perannya terhadap keterikatan kerja secara umum maupun peran setiap aspek trait mindfulness secara lebih spesifik. Penelitian ini melihat seluruh variabel sebagai konstruk tunggal dan bukan per dimensi. Agar lebih memahami dinamika di antara ketiga variabel tersebut, penelitian selanjutnya dapat melakukan analisis hingga tingkat dimensi sehingga diketahui dimensi mana yang paling mempengaruhi dan paling terpengaruh oleh variabel lainnya.

\section{SIMPULAN}

Berdasarkan hasil penelitian ini, dapat disimpulkan bahwa trait mindfulness berpengaruh terhadap keterikatan kerja melalui modal psikologis sebagai mediator. Hubungan mediasi tersebut bersifat parsial, yang artinya trait mindfulness memiliki pengaruh langsung dan tidak langsung terhadap keterikatan kerja melalui peran mediasi modal psikologis.

\section{SARAN}

Temuan dari penelitian ini berkontribusi terhadap literatur tentang manfaat mindfulness dalam konteks organisasi dan pekerjaan, terutama di negara Asia sebab belum banyak penelitian di Asia yang melihat manfaat mindfulness dalam konteks pekerjaan.

Bila memungkinkan, penelitian berikutnya dapat mempertimbangkan faktor organisasi lainnya seperti company size dan budaya organisasi agar dapat lebih memahami dinamika pengaruh mindfulness karyawan terhadap modal psikologis dan keterikatan kerja. Selain itu, pada penelitian ini trait mindfulness dilihat sebagai konstruk unidimensional. Penelitian selanjutnya dapat melihat konsepsi trait mindfulness lainnya untuk memperdalam pemahaman mengenai trait mindfulness dan dampaknya terhadap variabel-variabel lain. Analisis hingga ke tingkat dimensi untuk setiap variabel juga dapat dilakukan untuk memperdalam dinamika hubungan antara trait mindfulness, modal psikologis, dan keterikatan kerja.

\section{DAFTAR PUSTAKA}

Anwar, R., \& Niode, S. H. M. (2017). The effects of learning organization towards employees' innovative behavior mediated by work engagement (A study in Indonesia). Advances in Intelligent Systems Research, 131, 159-164. Diperoleh dari https://download.atlantispress.com/article/25880027.pdf.

Avey, J. B., Avolio, B. J., \& Luthans, F. (2011). Experimentally analyzing the impact of leader positivity on follower positivity and performance. The Leadership Quarterly, 22(2), 282-294.

doi: 10.1016/j.leaqua.2011.02.004.

Avey, J. B., Reichard, R. J., Luthans, F., \& Mhatre, K. H. (2011). Meta-analysis of the impact of positive psychological capital on employee attitudes, behaviors, and performance. Human Resource 
Development Quarterly, 22(2), 127 152. doi: 10.1002/hrdq.20070.

Avey, J. B., Wernsing, T. S., \& Luthans, F. (2008). Can positive employees help positive organizational change? Impact of psychological capital and emotions on relevant attitudes and behaviors. Journal of Applied Behavioral Science, 44, 48-70. doi: 10.1177/0021886307311470.

Ayu, D. A., Maarif, S., \& Sukmawati, A. (2015). Pengaruh job demands, job resources, dan personal resources terhadap work engagement. Jurnal Aplikasi Bisnis dan Manajemen (JABM), l(1), 12-22. doi: 10.17358/JABM.1.1.12.

Bakker, A.B. (2009). Building engagement in the workplace. In R. J. Burke \& C.L. Cooper (Eds.), The peak performing organization (pp. 50-72). Oxon, UK: Routledge.

Bakker, A. B., \& Albrecht, S. (2018). Work engagement: Current trends. Career Development International, 23(1), 411. doi: https://doi.org/10.1108/CDI11-2017-0207.

Bakker, A. B., Demerouti, E., \& SanzVergel, A. I. (2014). Burnout and work engagement: The JD-R approach. Annual Review of Organizational Psychology and Organizational Behavior, 1(1), 389411.

Brown, K. W., \& Ryan, R. M. (2003). The benefits of being present: Mindfulness and its role in psychological wellbeing. Journal of Personality and Social Psychology, 84, 822-848. doi:10.1037/00223514.84.4.822.

Byrne, E. K., \& Thatchenkery, T. (2019). Cultivating creative workplaces through mindfulness. Journal of Organizational Change Management, 32(1), 15-31. doi: 10.1108/JOCM-10-2017-0387.

Chaudhary, R., \& Rangnekar, S. (2017). Socio-demographic factors, contextual factors, and work engagement: Evidence from India. Emerging Economic Studies, 3(1), $1-18$. doi: $10.1177 / 2394901517696646$.

Cohen, R. J., \& Swerdlik, M. (2009). Psychological testing and assessment: An introduction to tests and measurement $\left(7^{\text {th }}\right.$ ed.). USA: McGraw-Hill.

Coo, C., \& Salanova, M. (2017). Mindfulness can make you happyand-productive: A mindfulness controlled trial and its effects on happiness, work engagement and performance. Journal of Happiness Studies: An Interdisciplinary Forum on Subjective Well-Being, 19(6), 1691-1711. doi: 10.1007/s10902017-9892-8.

Daniswara, A. (2012). Hubungan psychological capital and work engagement among nurse (Skripsi). Universitas Indonesia, Depok, Indonesia.

Depenbrock, F. (2014). Being mindfully aware and engaged at work? The role of affect regulative processes for the relationship between daily levels of mindfulness and work engagement (Tesis). Maastricht University, Maastricht, Belanda.

Deviyanti, A. D., \& Sasono, A. D. (2015). Pengaruh sumber daya pekerjaan (Job resources) dengan keterikatan kerja (Work engagement) sebagai mediator terhadap perilaku proaktif (Studi pada karyawan PT RGA International Indonesia). e-Jurnal Ilmu Manajemen MAGISTRA, 1(1), 16-30. Diperoleh dari https://jurnal.narotama.ac.id/index.p hp/magistra/article/view/22/21

Dupuis, M., Khadeer, S., \& Huang, J. (2017). "I Got the Job!": An exploratory study examining the psychological factors related to status updates on Facebook. Computers in Human Behavior, 73, 132-140. 
http://dx.doi.org/10.1016/j.chb.2017 .03.020.

Garland, E., Gaylord, S., \& Park, J. (2009). The role of mindfulness in positive reappraisal. Explore, 5(1), 37-44. doi:10.1016/j.explore.2008.10.001

Gunasekara, A., \& Zheng, C. S. (2018). Examining the effect of different facets of mindfulness on work engagement. Employee Relations, $41(1)$, 193-208. https://doi.org/10.1108/ER-092017-0220.

Glomb, T. M., Duffy, M. K., Bono, J. E., \& Yang, T. (2011). Mindfulness at work. Research in Personnel and Human Resources Management, 30, 115-157. http://dx.doi.org/10.1108/S07427301(2011)0000030005.

Han, Y., \& Zhang, Z. X. (2011, July). Enhancing managerial mindfulness: A way for middle managers to handle the uncertain situations. Paper dipresentasikan dalam the IACM Annual Conference, Istanbul, Turki. doi: $10.2139 /$ ssrn. 1872142 .

Hayes, A. F. (2013). Introduction to mediation, moderation, and conditional process analysis: A regression-based approach. NY: The Guilford Press.

Hülsheger, U. R., Alberts, H. J. E. M., Feinholdt, A., \& Lang, J. W. B. (2012). Benefits of mindfulness at work: The role of mindfulness in emotion regulation, emotional exhaustion, and job satisfaction. Journal of Applied Psychology, 98(2), 310-325. doi:10.1037/a0031313.

Jaworek, M. (2017). The role of occupational and demographic factors in relation to work engagement in Polish sample of employees - initial study. Journal of Positive Management, 8, 44-57. doi: http://dx.doi.org/10.12775/JPM.201 7.130 .
Kimberly. (2013). Hubungan psychological well-being dan work engagement pada karyawan yang bekerja di lokasi tambang (Skripsi). Universitas Indonesia, Depok, Indonesia.

Kotzé, M. (2017). The influence of psychological capital, selfleadership, and mindfulness on work engagement. South African Journal of Psychology, 1-14. doi: 10.1177/0081246317705812.

Luthans, F., Avolio, B. J., Avey, J. B., \& Norman, S. M. (2007). Positive psychological capital: Measurement and relationship with performance and satisfaction. Personnel Psychology, 60, 541-572.

Luthans, F., \& Youssef, C. M. (2007). Emerging positive organizational behavior. Journal of Management, 33, 321-349.

Luthans, F., Youssef, C. M., \& Avolio, B. J. (2007). Psychological capital: Developing the human competitive edge. New York: Oxford University Press, Inc.

Mäkikangas, A., Feldt, T., Kinnunen, U., \& Mauno, S. (2013), Does personality matter? A review of individual differences in occupational wellbeing, in Arnold B. Bakker (ed.) Advances in Positive Organizational Psychology, 1, 107-143.

Malinowski, P., \& Lim, H. J. (2015). Mindfulness at work: Positive affect, hope, and optimism mediate the relationship between dispositional mindfulness, work engagement, and well-being. Mindfulness, 6(6), 12501262. doi: 10.1007/s12671-0150388-5

Merissa, B. (2018). Pengaruh work engagement terhadap turnover intention melalui job satisfaction sebagai variabel mediasi pada PT. Lotte Shopping Indonesia Sidoarjo. AGORA, 6(1). Diperoleh dari https://media.neliti.com/media/publi cations/287290-pengaruh-work- 
engagement-terhadap-turnov-

9af73ec6.pdf.

Mesmer-Magnus, J., Manapragada. A., Viswesvaran, C., \& Allen, J. W. (2017). Trait mindfulness at work: A meta-analysis of the personal and professional correlates of trait mindfulness. Human Performance, 30(2-3), 79-98. doi: 10.1080/08959285.2017.1307842.

Millar, C. C. J. M., Groth, O., \& Mahon, J. F. (2018). Management innovation in a VUCA world: Challenges and recommendations. California Management Review, 110. doi: $10.1177 / 0008125618805111$.

Montani, F., Dagenais-Desmarais, V., Giorgi, G., \& Grégoire, S. (2016). A conservation of resources perspective on negative affect and innovative work behaviour: The role of affect activation and mindfulness. Journal of Business Psychology, 33(1), 123-139. doi: 10.1007/s10869-016-9480-7

Petchsawang, P., \& McLean, G. N. (2017). Workplace spirituality, mindfulness meditation, and work engagement. Journal of Management, Spirituality \& Religion, 14(3), 216-244. doi: 10.1080/14766086.2017.1291360

Podsakoff, P. M., MacKenzie, S. B., Lee, J. Y., \& Podsakoff, N. P. (2003). Common method biases in behavioral research: A critical review of the literature and recommended remedies. Journal of Applied Psychology, 88(5), 879-903. https://doi.org/10.1037/00219010.88.5.879

Roche, M., Haar, J. M., \& Luthans, F. (2014). The role of mindfulness and psychological capital on the wellbeing of leaders. Journal of Occupational Health Psychology, 19(4), 476-489. doi: http://dx.doi.org/10.1037/a0037183.

Rotich, R. K., Cheruiyot, T. K., \& Korir, M. K. (2016). Effects of demographics on the relationship between optimism and work engagement among employees of state agencies in Kenya. Journal of Resources Development and Management, 18, 32-42.

Samios, C. (2018). Burnout and psychological adjustment in mental health workers in rural Australia: the roles of mindfulness and compassion satisfaction. Mindfulness, 9, 10881099.

doi: https://doi.org/10.1007/s12671-0170844-5.

Schaufeli, W. B., \& Bakker, A. B. (2010). Defining and measuring work engagement: Bringing clarity to the concept. In A. B. Bakker (Ed.) \& M. P. Leiter, Work engagement: A handbook of essential theory and research (pp. 10-24). New York, NY, US: Psychology Press.

Schaufeli, W. B., Bakker, A. B., \& Salanova, M. (2006). The measurement of work engagement with a short questionnaire: A cross-national study. Educational and Psychological Measurement, 66(4), 701-716. doi:10.1177/0013164405282471.

Schaufeli, W. B., Salanova, M., GonzálezRomá, V., \& Bakker, A. B. (2002). The measurement of engagement and burnout: A two sample confirmatory factor analytic approach. Journal of Happiness Studies: An Interdisciplinary Forum on Subjective Well-Being, 3(1), 7192. doi: http://dx.doi.org/10.1023/A:101563 0930326.

Shapiro, S. L., Carlson, L. E., Astin, J. A., \& Freeman, B. (2006). Mechanisms of mindfulness. Journal of Clinical Psychology, 62(3), 373-386. doi: 10.1002/jclp.20237.

Simons, J. C., \& Buitendach, J. H. (2013). Psychological capital, work engagement and organisational commitment amongst call centre employees in South Africa. SA 
Journal of Industrial Psychology/SA Tydskrif vir Bedryfsielkunde, 39(2), 1-12. doi: http://dx.doi.org/10.4102/ sajip.v39i2.1071.

Sutrisno, M. B., \& Parahyanti, E. (2017). The impact of psychological capital and work meaningfulness on work engagement in Generation $\mathrm{Y}$. Advances in Social Science, Education and Humanities Research, 139, 53-58. https://dx.doi.org/10.2991/uipsur17.2018.9.

Tabaziba, K. R. (2015). Psychological capital and work engagement: An investigation into the mediating effect of mindfulness (Tesis). University of Cape Town, Cape Town, South Africa.

Takwin, B. (2019). Pesan dari Editor-inChief: Riset psikologi sosial yang dibutuhkan Indonesia. Jurnal Psikologi Sosial, 17(2), 59-64. doi: 10.7454/jps.2019.9.

Taylor, N. Z., \& Millear, P. M. R. (2016). The contribution of mindfulness to predicting burnout in the workplace. Personality and Individual Differences, 89, 123-128. doi: http://dx.doi.org/10.1016/j.paid.201 5.10.005.

Wiroko, E. P., \& Evanytha. (2019). Mindfulness and work engagement among generation Y. Psycho Idea, 17(2), 154-163.

Xanthopoulou, D., Bakker, A. B., Demerouti, E., \& Schaufeli, W. B. (2007). The role of personal resources in the job demandsresources model. International Journal of Stress Management, 14(2), 121-141. doi: 10.1037/10725245.14.2.121.

Zheng, S., Gunasekara, A., \& Blaich, S. (2018). Mindfulness and work engagement: The mediating effect of psychological flourishing. Academy of Management Annual Meeting Proceedings.
10.5465/AMBPP.2018.12210abstra

ct. 